\title{
Nutritional status, production and fruit quality of west indian cherry fertigated with nitrogen and humic substance
}

\author{
Dayanne do Nascimento Dias ${ }^{1}$, Karla dos Santos Melo de Sousa ${ }^{2}$, Augusto Miguel Nascimento Lima ${ }^{2}$, \\ Ítalo Herbert Lucena Cavalcante ${ }^{2}$, Laura Paula Araújo dos Santos ${ }^{1}$, Jailson Cavalcante Cunha ${ }^{3}$
}

\begin{abstract}
Information on humic substances (HS) associated with nitrogen fertilization in West Indian cherry is scarce in the literature. The use of soil conditioners, such as HS, can increase the efficiency in the absorption of nutrients, especially N. Therefore, the present study aimed to evaluate, in two production cycles, the fruit quality, yield and nutritional status of West Indian cherry as a function of fertigation with nitrogen $(\mathrm{N})$ and HS in Petrolina-PE, Brazil. The experimental design was in split plots, with treatments distributed in $5 \times 2$ strips, referring to $\mathrm{N}$ doses $(50,75,100,125$ and $150 \%$ of the recommended dose) and HS application (without and with), respectively, with 4 replicates and 3 plants per plot. The $\mathrm{N}$ source used was urea $(45 \% \mathrm{~N})$ and the HS source used was the commercial product KS100 $\left(\mathrm{Omnia}^{\circledR}\right)$, from leonardite, monthly applied at dose of $6 \mathrm{~g} \mathrm{plant}^{-1}$. Production, yield, indices of chlorophyll $a$, chlorophyll $b$ and total chlorophyll, and leaf contents of $\mathrm{N}, \mathrm{P}, \mathrm{K}, \mathrm{Na}, \mathrm{Ca}, \mathrm{Mg}, \mathrm{Fe}$, $\mathrm{Mn}$ and $\mathrm{Zn}$ were determined. Fruits were evaluated for: $\mathrm{pH}$, vitamin $\mathrm{C}$, soluble solids (SS), titratable acidity (TA) and SS/TA ratio. Except for leaf $\mathrm{N}$ content, which increased linearly with the applied doses, the leaf contents of nutrients, production and yield of West Indian cherry showed a stochastic pattern as a function of the increase in $\mathrm{N}$ availability and $\mathrm{HS}$ application. West Indian cherry plants cultivated and fertilized according to the recommendation for the crop did not respond to the evaluated treatments. Application of humic substances and $\mathrm{N}$ doses did not alter the post-harvest quality of West Indian cherry fruits.
\end{abstract}

Index terms: Malpighia emarginata, plant nutrition, nitrogen fertilization, humic acid, production.

\section{Estado nutricional, produção e qualidade do fruto da aceroleira fertirrigada com nitrogênio e substância húmica}

Corresponding author:

dayanne-dias@outlook.com

\section{Received: July 11, 2019}

Accepted: November 11, 2019

Copyright: All the contents of this journal, except where otherwise noted, is licensed under a Creative Commons Attribution License.

\section{(cc) $\mathbf{E Y}$}

Resumo- As informações das substâncias húmicas (SH), associadas à fertilização nitrogenada na cultura da aceroleira, são escassas na literatura. O uso de condicionadores do solo, como as $\mathrm{SH}$, pode incrementar a eficiência da absorção de nutrientes, principalmente o N. Com isso, o presente trabalho teve por objetivo avaliar, em dois ciclos de produção, a qualidade de frutos, a produtividade e o estado nutricional da aceroleira em função da fertirrigação com nitrogênio (N) e $\mathrm{SH}$, em Petrolina-PE. O delineamento experimental foi em parcelas subdivididas com tratamentos distribuídos em faixas $5 \times 2$, referentes às doses de $\mathrm{N}(50 ; 75 ; 100 ; 125$ e $150 \%$ da dose recomendada) e aplicação de SH (sem e com), respectivamente, com 4 repetições e 3 plantas por parcela. A fonte de $\mathrm{N}$ utilizada foi a ureia $(45 \%$ de $\mathrm{N})$, e a fonte de $\mathrm{SH}$ utilizada foi o produto comercial KS100 (Omnia $\left.{ }^{\circledR}\right)$, proveniente de leonardita, aplicando mensalmente 6 g planta ${ }^{-1}$. Foram determinados a produção, produtividade, os índices de clorofila $\mathrm{a}, \mathrm{b}$ e total, e os teores foliares de $\mathrm{N}, \mathrm{P}, \mathrm{K}, \mathrm{Na}, \mathrm{Ca}, \mathrm{Mg}, \mathrm{Fe}$, Mn e $\mathrm{Zn}$. Nos frutos, determinaram-se: $\mathrm{pH}$, vitamina $\mathrm{C}$, sólidos solúveis (SS), acidez titulável (AT) e a relação SS/AT. Com exceção do Nitrogênio foliar, que teve um aumento linear com as doses aplicadas, os teores foliares de nutrientes, a produção e a produtividade de aceroleira apresentaram um padrão estocástico em relação ao aumento da disponibilidade de $\mathrm{N}$ e aplicação de substâncias húmicas. As plantas de aceroleira cultivadas e adubadas de acordo com a recomendação para a cultura não responderam aos tratamentos avaliados. A aplicação de substâncias húmicas e de doses de $\mathrm{N}$ não alterou a qualidade pós-colheita de frutos de aceroleira. Termos para indexação: Malpighia emarginata, Nutrição de plantas, adubação nitrogenada, ácido húmico, produção. 


\section{Introduction}

West Indian cherry (Malpighia emarginata) is a tropical climate plant with broad economic and nutritional potential, mainly due to the high vitamin $C$ content present in its fruits. Brazil stands out as the world's largest producer of West Indian cherry, with about 143 thousand tons per year, and the Northeast region is responsible for approximately $35 \%$ of the national production (IBGE, 2017).

West Indian cherry production can be influenced by several factors such as soil, climate, fertilization and irrigation management practices, which will directly affect plant performance in the field and, consequently, fruit yield and quality (FRANZÃO; MELO, 2003).

According to Ferreira (2014), as it has production capacity of up to six crops per year, West Indian cherry is demanding in terms of nutrients, mainly nitrogen $(\mathrm{N})$ and potassium $(\mathrm{K})$, both in the initial growth and development stage and in the production stage. Nitrogen fertilization is very important, as this nutrient influences plant growth, and its deficiency will directly affect fruit development and production (MIRANDA et al., 2015). Excess N, on the other hand, is also harmful because it stimulates excessive vegetative development of the plant, with effects on fruit quality and especially on the incidence of physiological disorders (ERNANI et al., 2008).

According to Hawkesford et al. (2012), the plant absorbs less than $50 \%$ of the $\mathrm{N}$ applied by fertilization. The remainder is lost by leaching, especially in sandy soils (PRASAD et al., 2015), so it may contaminate water sources and groundwater (NOWAKI et al., 2017).

Cunha et al. (2015) point out that the use of soil conditioners to increase the efficiency in the absorption of nutrients, especially $\mathrm{N}$, has been widely studied, and an alternative is the use of humic substances (HS). HS are formed by the transformation of biomolecules in the decomposition of soil organic matter, with a widely recognized influence on the chemical, physical and biological properties of the soil and, consequently, on root growth, increase of nutrient absorption and biosynthesis of chlorophylls (FERRARA; BRUNETTI, 2008). Some of the effects of the HS $+\mathrm{N}$ mixture are related to the dynamics of ammoniacal $\mathrm{N}$ in soil, because humic acid (HA) associated with urea possibly reduces the action of the urease enzyme, thus causing a reduction in $\mathrm{N}$ losses in addition to a buffering effect on soil pH (DONG et al., 2009).

Silva et al. (2016), evaluating the nutritional status and yield of yellow passion fruit as a function of fertigation with $\mathrm{N}$ and HS, concluded that the application of HS and $\mathrm{N}$ doses led to an exponential increase in leaf $\mathrm{N}$ content in yellow passion fruit, as well as in its stem diameter, production per plant and yield, and highest yields were obtained at $\mathrm{N}$ doses of $290\left(16.5 \mathrm{t} \mathrm{ha}^{-1}\right)$ and $350 \mathrm{~kg} \mathrm{ha}^{-1}$
(17.5 $\left.\mathrm{t} \mathrm{ha}^{-1}\right)$ without and with HS, respectively.

When evaluating the effect of HS application and $\mathrm{N}$ fertilization on sugar-apple fruit quality and yield, Cunha et al. (2015) observed that, in plants that received HS, the contents of soluble solids (SS) in the fruits increased by approximately $2.8 \%$ after using 0 to $100 \mathrm{~g}$ of $\mathrm{N}$ per plant and decreased by $6.25 \%$ after using 100 to $250 \mathrm{~g}$ of $\mathrm{N}$ per plant, while the use of HS caused an exponential increase in the $\mathrm{SS} / \mathrm{TA}$ ratio as the $\mathrm{N}$ levels increased.

According to Lima et al. (2006), monitoring the seasonal variation of leaf nutrient contents allows establishing patterns of nutritional management aiming to achieve and maintain high yield and quality of West Indian cherry fruits.

Thus, the present study aimed to evaluate, in two production cycles, the yield and nutritional status of West Indian cherry as a function of $\mathrm{N}$ fertigation and HS application, as well as the post-harvest quality of the fruits.

\section{Material and methods}

\section{Experimental area and crop management}

The experiment was conducted in two production cycles, the first from February to July 2016 and the second from September 2016 to February 2017, at the fruit production sector of the Agrarian Sciences campus of the Federal University of São Francisco Valley, located in Petrolina-PE, Brazil, located at the geographic coordinates - latitude: $09^{\circ} 19^{\prime} 28^{\prime \prime}$, longitude: $40^{\circ} 33^{\prime} 34^{\prime \prime} \mathrm{W}$, altitude: $393 \mathrm{~m}$. The climate of the region is hot and dry in the winter, being classified by Köppen as BSh, semiarid, with average precipitation of $538.7 \mathrm{~mm}$ year ${ }^{-1}$, distributed from November to April, and average annual temperature of $26.2^{\circ} \mathrm{C}$. The soil of the area is classified as Argissolo Amarelo eutrocoeso típico (Ultisol) (SILVA et al., 2017), with sand contents of $894.22 \mathrm{~g} \mathrm{~kg}^{-1}$ and $843.22 \mathrm{~g} \mathrm{~kg}^{-1}$, clay contents of $95 \mathrm{~g} \mathrm{~kg}^{-1}$ and $138 \mathrm{~g} \mathrm{~kg}^{-1}$, and silt contents of $10.78 \mathrm{~g} \mathrm{~kg}^{-1}$ and $18.78 \mathrm{~g} \mathrm{~kg}^{-1}$ in the $0-20$ and $20-40 \mathrm{~cm}$ layers, respectively.

Along the experiment, climatic data were collected at the meteorological station installed on the Agrarian Sciences campus (Figure 1). 


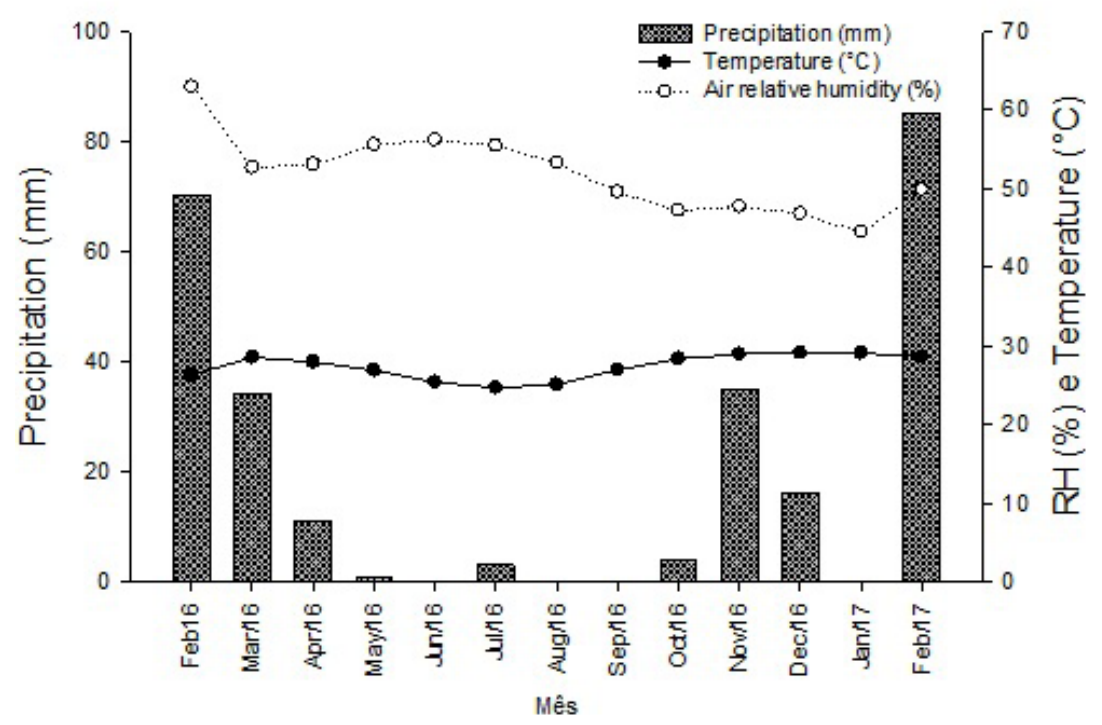

Figure 1. Monthly precipitation, temperature and air relative humidity $(\mathrm{RH})$ along the experiment.

Before installing the experiment, 20 single soil samples were collected in the $0-20$ and $20-40 \mathrm{~cm}$ layers, in order to form a composite sample of each layer to determine the chemical attributes of the soil (Table 1).

Table 1. Chemical attributes of the soil in the 0-20 and 20-40 $\mathrm{cm}$ layers before installing the experiment.

\begin{tabular}{ccc}
\hline Attributes & $\mathbf{0 - 2 0} \mathbf{~ c m}$ & $\mathbf{2 0 - 4 0 ~ c m ~}$ \\
\hline $\mathrm{pH}^{1 /}$ & 6.54 & 5.86 \\
$\mathrm{CEC}^{2 /}\left(\mathrm{cmol}_{\mathrm{c}} \mathrm{dm}^{-3}\right)$ & 8.83 & 7.12 \\
$\mathrm{Ca}^{2+}\left(\mathrm{cmol}_{\mathrm{c}} \mathrm{dm}^{-3}\right)$ & 4.02 & 1.75 \\
$\mathrm{Mg}^{2+}\left(\mathrm{cmol}_{\mathrm{c}} \mathrm{dm}^{-3}\right)$ & 0.42 & 0.53 \\
$\mathrm{~K}^{+}\left(\mathrm{cmol}_{\mathrm{c}} \mathrm{dm}^{-3}\right)$ & 0.35 & 0.33 \\
$\mathrm{Na}^{+}\left(\mathrm{cmol}_{\mathrm{c}} \mathrm{dm}^{-3}\right)$ & 0.04 & 0.04 \\
$\mathrm{Al}^{3+}\left(\mathrm{cmol}_{\mathrm{c}} \mathrm{dm}^{-3}\right)$ & 0.29 & 0.12 \\
$\mathrm{H}+\mathrm{Al}^{3 /}\left(\mathrm{cmol}_{\mathrm{c}} \mathrm{dm}^{-3}\right)$ & 4.24 & 4.62 \\
$\mathrm{P}\left(\mathrm{mg} \mathrm{dm}^{-3}\right)$ & 198.68 & 191.71 \\
$\mathrm{Fe}^{2+}\left(\mathrm{mg} \mathrm{dm}^{-3}\right)$ & 71.61 & 85.83 \\
$\mathrm{Mn}^{2+}\left(\mathrm{mg} \mathrm{dm}^{-3}\right)$ & 221.08 & 108.24 \\
$\mathrm{Zn}^{2+}\left(\mathrm{mg} \mathrm{dm}^{-3}\right)$ & 1.06 & 0.65 \\
$\mathrm{~V}^{4 /}(\%)$ & 52.01 & 35.03 \\
$\mathrm{TOC}^{5 /}\left(\mathrm{t} \mathrm{ha}^{-1}\right)$ & 22.78 & 12.25 \\
\hline
\end{tabular}

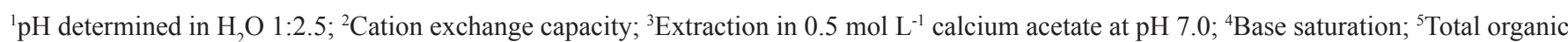
carbon; $\mathrm{P}, \mathrm{K}^{+}, \mathrm{Na}^{+}, \mathrm{Fe}^{2+}, \mathrm{Mn}^{2+}$ and $\mathrm{Zn}^{2+}$ : Mehlich-1 Extractor; $\mathrm{Al}^{3+}, \mathrm{Ca}^{2+}$ and $\mathrm{Mg}^{2+}: 1$ mol L-1 $\mathrm{KCl}$ Extractor. Silva (2009)

\section{Orchard planting and conduction}

West Indian cherry seedlings of the 'Junko' variety were planted in June 2015 at spacing of $4 \mathrm{~m}$ between rows and $3 \mathrm{~m}$ between plants, in $50 \times 50 \times 50 \mathrm{~cm}$ holes, and irrigated with a sprinkler system (flow rate of $42 \mathrm{~L}$ $\mathrm{h}^{-1}$ ). At planting, basal fertilization was performed with 20 g plant $^{-1}$ of $\mathrm{P}_{2} \mathrm{O}_{5}$ and 30 g plant $^{-1}$ of $\mathrm{K}_{2} \mathrm{O}$, using single superphosphate $\left(18 \% \mathrm{P}_{2} \mathrm{O}_{5}\right)$ and potassium chloride - $\mathrm{KCl}$ $\left(60 \% \mathrm{~K}_{2} \mathrm{O}\right)$ as sources, respectively. $20 \mathrm{~L} \mathrm{plant}^{-1}$ of cured bovine manure were also applied.
During the development of West Indian cherry seedlings, stakes were used to direct their growth and, as they reached height of $30-40 \mathrm{~cm}$, formative pruning was performed in order to grow each plant on a single stake. Three lateral branches were left and, after the plant was $50 \mathrm{~cm}$ tall, tipping was performed in order to break apical dominance. Branches that were competing for light were eliminated and, systematically after each production cycle, renovation and cleaning pruning operations were carried out in order to keep the plants at adequate height. 
All management practices for pruning and control of weeds, pests and diseases were performed according to Barboza et al. (1996).

\section{Experimental design and treatments}

The experimental design adopted was in split plots, with treatments distributed in $5 \times 2$ strips, referring to 5 doses of $\mathrm{N}(50,75,100,125$ and $150 \%$ of the recommended dose) and 2 alternatives for the application of humic substances (with and without), with 4 replicates and 3 plants per subplot. $\mathrm{N}$ doses were defined according to the fertilization recommendations for the state of Pernambuco (CAVALCANTI et al., 2008): $100 \mathrm{~g} \mathrm{~N}$ plant $^{-1}$ at planting (growth), $150 \mathrm{~g} \mathrm{~N}$ plant $^{-1}$ in the first year of production, $200 \mathrm{~g} \mathrm{~N}$ plant $^{-1}$ in the second year, and $250 \mathrm{~g}$ $\mathrm{N}_{\text {plant }}{ }^{-1}$ from the third year onwards.

The $\mathrm{N}$ source used was urea $(45 \% \mathrm{~N})$ with weekly applications, from 60 days after transplantation (DAT). At growth and production stages, $\mathrm{N}$ doses were split into ten applications, as recommended by Cavalcanti et al. (2008). The source of humic substances (HS) used in the experiment was the commercial product $\mathrm{KS} 100\left(\mathrm{Omnia}^{\circledR}\right)$, from Australian leonardite, whose composition is $\mathrm{K}_{2} \mathrm{O}$ $(15 \%)$, total organic carbon (45\%), humic acids $(70 \%)$ and fulvic acids (8\%). The values of electrical conductivity, salt index, $\mathrm{pH}$ and solubility are, respectively, $0.37 \mathrm{mS}$ $\mathrm{cm}^{-1}, 24,10$ and $140 \mathrm{~g} \mathrm{~L}^{-1}$. Fertigation with HS began at 30 DAT, with monthly applications of $6 \mathrm{~g} \mathrm{plant}^{-1}$ of KS100 until the end of the experiment, as recommended by the manufacturer.

Fertilization with $\mathrm{K}$ was also performed, using $\mathrm{KCl}$ $\left(60 \% \mathrm{~K}_{2} \mathrm{O}\right)$ as source and $130 \mathrm{~g} \mathrm{~K}_{2} \mathrm{O}_{\text {plant }}{ }^{-1}$, split into ten weekly applications from 90 DAT. Foliar fertilization with micronutrients $\left(4.5 \mathrm{~g} \mathrm{Zn} \mathrm{plant}^{-1}\right.$ and $1 \mathrm{~g} \mathrm{~B}$ plant $\left.^{-1}\right)$ was performed in two applications from 90 DAT, using as a source the commercial products Nutrigema, whose composition has B $\left(67.7 \mathrm{~g} \mathrm{~L}^{-1}\right)$ and $\mathrm{Zn}\left(67.7 \mathrm{~g} \mathrm{~L}^{-1}\right)$, and Folimax Zinco, whose composition has $\mathrm{Zn}\left(118.89 \mathrm{~g} \mathrm{~L}^{-1}\right)$ and TOC $\left(15.88 \mathrm{~g} \mathrm{~L}^{-1}\right)$, following the recommendation of Cavalcanti et al. (2008). Fertilization management was performed using a fertigation system (1-inch-diameter Viqua $^{\circledR}$ venturi injector at operating pressure of 10 bar).

\section{Variables analyzed and statistical evaluation}

At the beginning of flowering, chlorophyll readings were performed in the diagnostic leaves still in the field, $3^{\text {rd }}$ or $4^{\text {th }}$ leaf from the apical bud of healthy intermediate branches, to determine chlorophyll indices ( $a, b$ and total) with a chlorophyll meter (Falker ${ }^{\circledR}$ Brazil), according to the recommendations of El-Hendawy (2005).

Next, the leaves were collected and, after drying and grinding the plant material in a Wiley-type mill, 0.5 -g portions of these samples were mineralized by dry digestion to determine macro- and micronutrient contents, according to methodologies described by Silva
(2009): I) Phosphorus (P): determined by UV-visible spectrophotometry; II) Potassium (K) and sodium (Na): determined by flame emission photometry; III) Calcium (Ca) and magnesium ( $\mathrm{Mg}$ ); IV) Iron ( $\mathrm{Fe})$, manganese $(\mathrm{Mn})$ and zinc $(\mathrm{Zn})$ : determined by atomic absorption spectrophotometry. Nitrogen $(\mathrm{N})$ was determined in solutions obtained from extracts prepared by sulfuric digestion, by the Kjeldahl method, according to Silva (2009).

Harvest was carried out twice a week, with manual collection of the fruits in the first hours of the day, at commercial maturity stage, when fruits show a red color, but are still firm to withstand handling. Throughout the harvesting period, fruits were weighed to determine the production per plant $\left(\mathrm{kg} \mathrm{plant}^{-1}\right)$, and then the yield $\left(\mathrm{tha}^{-1}\right)$ was determined in each treatment.

After that, the fruits were sent to the Agroindustry Laboratory for post-harvest evaluation. Initially, the fruits were washed, sanitized with sodium hypochlorite solution (200 $\mathrm{m} \mathrm{L} \mathrm{L}^{-1}$ ) and washed again with running water to remove excess solution. Then they were disintegrated in a domestic blender and sieved to obtain the pulp.

West Indian cherry pulp analyses followed the instructions of the Adolfo Lutz Institute (2008), including: i) $\mathrm{pH}$, determined by potentiometry; (ii) soluble solids (SS), using an Abbe-type refractometer, with results expressed in ${ }^{\circ}$ Brix; iii) titratable acidity (TA), expressed in grams of citric acid per $100 \mathrm{~g}$ of pulp, determined by titration with sodium hydroxide $(0.1 \mathrm{~N})$ using $1 \%$ phenolphthalein as indicator; iv) soluble solids to titratable acidity ratio (SS/TA); v) ascorbic acid (VIT C), determined according to the AOAC method (1997), expressed in mg $100 \mathrm{~g}^{-1}$. All analyses were performed in triplicate.

The data were subjected to analysis of variance to identify significant effects between production cycles, $\mathrm{N}$ doses and HS, by the F test. Treatments without and with HS and the production cycle factor were compared by the Scott-Knott test at $1 \%$ and $5 \%$ probability levels (SILVA; AZEVEDO, 2009), whereas N doses were evaluated by regression.

\section{Results and discussion}

The triple interaction $(\mathrm{CxHSxN})$ had significant effects on the production $(p<0.01)$ and yield $(p<0.01)$ of West Indian cherry (Table 2). Significant triple interaction was also observed for $\mathrm{K}$ content in the leaf tissue of West Indian cherry (Table 3). 
Table 2. Summary of analysis of variance for production (Pp), yield (Y) and indices of chlorophyll $a$, chlorophyll $b$ and total chlorophyll of West Indian cherry plants fertigated with nitrogen $(\mathrm{N})$ and humic substances (HS).

\begin{tabular}{|c|c|c|c|c|c|}
\hline Source of Variation & $\begin{array}{c}\mathrm{Pp} \\
\left(\mathrm{kg} \mathrm{plant}^{-1}\right)\end{array}$ & $\begin{array}{c}\mathrm{Y} \\
\left(\mathrm{t} \mathrm{ha}^{-1}\right)\end{array}$ & Chlorophyll $a$ & $\begin{array}{c}\text { Chlorophyll } b \\
\text { ICF }\end{array}$ & Chlorophyll total \\
\hline Cicle I & $11.47 \mathrm{~b}$ & $9.56 b$ & $34.93 b$ & $12.44 \mathrm{~b}$ & $47.37 \mathrm{~b}$ \\
\hline Cicle II & $25.07 \mathrm{a}$ & $20.99 a$ & $39.78 \mathrm{a}$ & $15.64 \mathrm{a}$ & $55.42 \mathrm{a}$ \\
\hline $\mathrm{CV}(\%)$ & 27.20 & 24.90 & 10.94 & 33.27 & 15.59 \\
\hline With HS & $15.56 \mathrm{~b}$ & $13.06 \mathrm{~b}$ & $36.94 a$ & $13.04 \mathrm{a}$ & $49.98 \mathrm{a}$ \\
\hline Without HS & $20.99 \mathrm{a}$ & $17.49 \mathrm{a}$ & $37.77 \mathrm{a}$ & $15.03 \mathrm{a}$ & $52.80 \mathrm{a}$ \\
\hline CV $(\%)$ & 16.22 & 17.23 & 11.75 & 28.98 & 15.28 \\
\hline \multicolumn{6}{|c|}{ Value $\mathbf{F}$} \\
\hline Cicle (C) & $149.78 * *$ & $180.75^{* *}$ & $28.14 * *$ & $9.39 *$ & $20.19 * *$ \\
\hline Humic Sub. (SH) & $67.13 * *$ & $56.58 * *$ & $0.72^{\mathrm{ns}}$ & $4.78^{\mathrm{ns}}$ & $2.59 \mathrm{~ns}$ \\
\hline Dose of $\mathrm{N}$ & $11.05^{* *}$ & $10.29 * *$ & $1.94^{\mathrm{ns}}$ & $1.53 \mathrm{~ns}$ & $1.79^{\mathrm{ns}}$ \\
\hline $\mathrm{CV}(\%)$ & 22.45 & 22.83 & 6.81 & 21.47 & 9.29 \\
\hline CxHS & $9.57 *$ & $7.48^{*}$ & $0.84^{\mathrm{ns}}$ & $0.07^{\mathrm{ns}}$ & $0.43^{\text {ns }}$ \\
\hline $\mathrm{CxN}$ & $2.46^{\mathrm{ns}}$ & $2.21 \mathrm{~ns}$ & $3.48^{*}$ & $6.48 * *$ & $6.47 * *$ \\
\hline HSxN & $14.40^{* *}$ & $13.29 * *$ & $0.57^{\mathrm{ns}}$ & $1.81^{\mathrm{ns}}$ & $1.38^{\mathrm{ns}}$ \\
\hline CxHSxN & $4.90 * *$ & $4.43 * *$ & $0.26^{\mathrm{ns}}$ & $2.06^{\mathrm{ns}}$ & $0.72^{\mathrm{ns}}$ \\
\hline
\end{tabular}

$\mathrm{ns}=$ not significant; $* *$ significant at $1 \%$ probability level; * significant at $5 \%$ probability level. Means followed by the same letter in the column do not differ statistically by $\mathrm{F}$ test with $\mathrm{P} \leq 0.05$.

Table 3. Summary of analysis of variance for $\mathrm{N}, \mathrm{Na}, \mathrm{K}, \mathrm{P}, \mathrm{Ca}, \mathrm{Mg}, \mathrm{Mn}, \mathrm{Zn}$ and Fe contents in the leaf tissue of West Indian cherry plants fertigated with nitrogen and humic substances in Petrolina-PE, Brazil.

\begin{tabular}{|c|c|c|c|c|c|c|c|c|c|}
\hline $\begin{array}{l}\text { Source of } \\
\text { Variation }\end{array}$ & $\mathrm{N}$ & $\mathrm{Na}$ & $\mathrm{K}$ & $\begin{array}{c}\mathrm{P} \\
-\mathrm{g} \mathrm{kg}^{-1}\end{array}$ & $\mathrm{Ca}$ & $\mathrm{Mg}$ & $\mathrm{Mn}$ & $\begin{array}{l}\mathrm{Zn} \\
\mathrm{mg} \mathrm{kg}^{-1}\end{array}$ & $\mathrm{Fe}$ \\
\hline Cicle I & $47.62 \mathrm{a}$ & $1.17 \mathrm{a}$ & $20.98 b$ & $229.24 b$ & $15.64 \mathrm{~b}$ & $4.12 b$ & $162.00 \mathrm{a}$ & $606.11 \mathrm{a}$ & $59.73 a$ \\
\hline Cicle II & $40.08 b$ & $1.20 \mathrm{a}$ & $34.68 \mathrm{a}$ & $317.15 \mathrm{a}$ & $43.57 \mathrm{a}$ & 7.91a & $182.63 a$ & $191.21 b$ & $68.06 \mathrm{a}$ \\
\hline CV $(\%)$ & 10.56 & 33.02 & 23.88 & 12.32 & 31.94 & 28.40 & 29.32 & 43.27 & 23.87 \\
\hline With SH & $44.11 \mathrm{a}$ & $1.13 \mathrm{a}$ & $26.98 \mathrm{a}$ & $274.49 a$ & $23.02 b$ & $5.59 b$ & $170.75 a$ & $308.52 b$ & $60.14 a$ \\
\hline Without SH & $43.59 \mathrm{a}$ & $1.25 \mathrm{a}$ & $28.68 \mathrm{a}$ & $271.89 a$ & $36.19 \mathrm{a}$ & $6.44 a$ & $173.88 \mathrm{a}$ & $488.80 \mathrm{a}$ & $67.64 \mathrm{a}$ \\
\hline CV (\%) & 14.67 & 33.42 & 24.51 & 23.93 & 32.70 & 22.10 & 17.45 & 17.79 & 30.29 \\
\hline \multicolumn{10}{|c|}{ Value F } \\
\hline Cicle (C) & $53.09 * *$ & $0.15^{\mathrm{ns}}$ & $84.90 * *$ & $136.33^{* *}$ & $174.48^{* *}$ & $98.13 * *$ & $3.33^{\text {ns }}$ & $115.68 * *$ & $5.96^{\text {ns }}$ \\
\hline $\begin{array}{c}\text { Humic } \\
\text { Sub. (HS) }\end{array}$ & 0.13 & 1.7 & 1.2 & 0.0 & 3 & * & ns & 1 & $3.00^{\mathrm{ns}}$ \\
\hline Dose of $N$ & $11.85 * *$ & $0.99^{\mathrm{ns}}$ & $1.66^{\mathrm{ns}}$ & $3.24 *$ & $0.79^{\text {ns }}$ & $0.38^{\text {ns }}$ & $1.08^{\text {ns }}$ & $1.33^{\mathrm{ns}}$ & $0.37^{\mathrm{ns}}$ \\
\hline CV $(\%)$ & 10.10 & 24.46 & 20.21 & 19.89 & 51.37 & 24.66 & 28.40 & 27.25 & 17.28 \\
\hline CxHS & $0.09^{\mathrm{ns}}$ & $1.64^{\mathrm{ns}}$ & $0.004^{\mathrm{ns}}$ & $0.24^{\mathrm{ns}}$ & $35.98 * *$ & $2.05^{\mathrm{ns}}$ & $3.02^{\mathrm{ns}}$ & $75.23 * *$ & $0.15^{\mathrm{ns}}$ \\
\hline $\mathrm{CxN}$ & $0.60^{\text {ns }}$ & $0.95^{\mathrm{ns}}$ & $2.07^{\mathrm{ns}}$ & $0.52^{\mathrm{ns}}$ & $0.85^{\mathrm{ns}}$ & $0.21^{\mathrm{ns}}$ & $2.46^{\mathrm{ns}}$ & $1.52^{\mathrm{ns}}$ & $4.08 * *$ \\
\hline HSxN & $1.47^{\mathrm{ns}}$ & $2.96^{*}$ & $2.79 *$ & $1.75^{\mathrm{ns}}$ & $0.37^{\mathrm{ns}}$ & $0.44^{\mathrm{ns}}$ & $0.86^{\mathrm{ns}}$ & $0.78^{\mathrm{ns}}$ & $2.49^{\mathrm{ns}}$ \\
\hline $\mathrm{CxHSxN}$ & $1.31^{\mathrm{ns}}$ & $0.23^{\mathrm{ns}}$ & $5.01 * *$ & $1.66^{\mathrm{ns}}$ & $0.37^{\mathrm{ns}}$ & $0.63^{\mathrm{ns}}$ & $2.09^{\mathrm{ns}}$ & $1.34^{\mathrm{ns}}$ & $1.54^{\mathrm{ns}}$ \\
\hline
\end{tabular}

$\mathrm{ns}=$ not significant; $* *$ significant at $1 \%$ probability level; * significant at $5 \%$ probability level. Means followed by the same letter in the column do not differ statistically by $\mathrm{F}$ test with $\mathrm{P} \leq 0.05$.

Regarding chlorophyll indices ( $a, b$ and total), there was an effect of the interaction between the West Indian cherry production cycle and $\mathrm{N}$ doses $(\mathrm{CxN})$ (Table 2). This double interaction was also significant for Fe content $(\mathrm{p}<$ 0.01 ) (Table 3 ) in the leaves, while the interaction between $\mathrm{HS}$ and $\mathrm{N}$ doses $(\mathrm{HSxN})$ caused significant differences in $\mathrm{Na}$ and $\mathrm{K}$ contents $(\mathrm{p}<0.05)$. Likewise, the interaction between production cycle and HS (CxHS) had significant effect on the leaf contents of $\mathrm{Ca}$ and $\mathrm{Zn}(\mathrm{p}<0.01)$.
Also in relation to the nutrient contents in the leaf tissue, HS application caused significant effect on $\mathrm{Mg}$ content $(\mathrm{p}<0.05)$. For $\mathrm{N}$ doses, there was an effect on the contents of $\mathrm{N}(\mathrm{p}<0.01)$ and $\mathrm{P}(\mathrm{p}<0.05)$ (Table 3$)$.

Although the application of $\mathrm{N}$ doses had significant effect on some variables in the plants, both as single factor and in interactions, no significant regression models were found for most variables analyzed. Thus, the treatments were analyzed considering the mean values and their corresponding standard deviations. 
Chlorophyll $a$ and total chlorophyll indices were higher in the second production cycle (Cycle 2) for most $\mathrm{N}$ doses (Figure 2A and 2C). Chlorophyll $b$ indices were not higher in Cycle 2 only at $\mathrm{N}$ doses of 75 and $100 \%$ (Figure 2B). The higher chlorophyll indices in Cycle $2 \mathrm{did}$ not corroborate the $\mathrm{N}$ contents in the leaf tissue (Table 3 ), whose values were higher in the first cycle of West Indian cherry (Cycle 1). N plays an important role in chlorophyll synthesis; however, in view of the high $\mathrm{N}$ contents found in the leaf tissue in the two production cycles - above the sufficiency range established by Bataglia and Santos (2001) for West Indian cherry (20-24 $\left.\mathrm{g} \mathrm{kg}^{-1}\right)$ - other factors possibly contributed to the higher chlorophyll indices in Cycle 2. Lobo et al. (2012) report that the relationship between the determination of chlorophyll contents and $\mathrm{N}$ concentration in the leaves depends on several factors such as: physiological stage, cultivar, climatic conditions, soil fertility, among others.
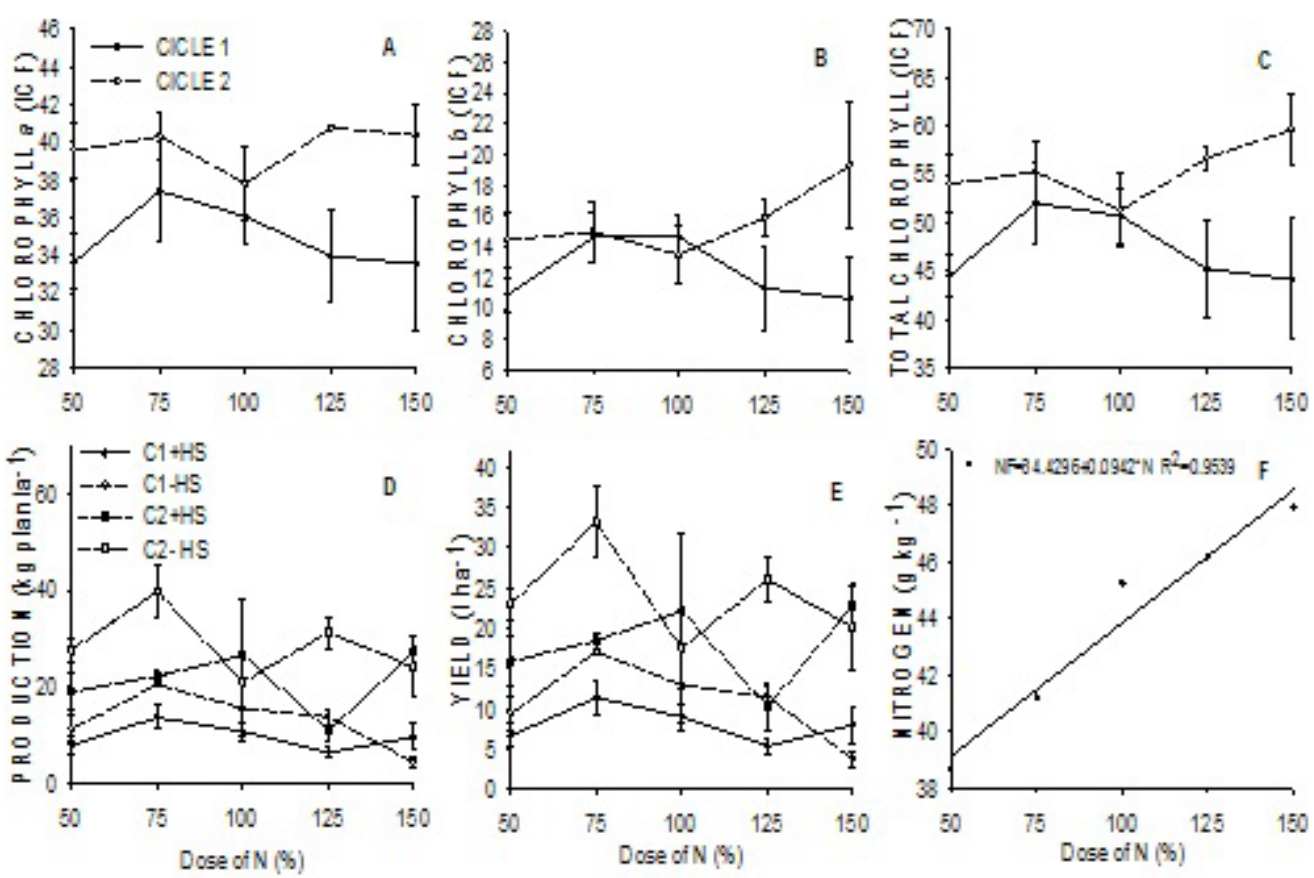

Figure 2. Chlorophyll $a$ (A), Chlorophyll $b$ (B), Total Chlorophyll (C), Production (D), Yield (E) and Leaf nitrogen content $(\mathrm{F})$ in West Indian cherry plants fertigated with nitrogen $(\mathrm{N})$ and humic substances (HS) in Petrolina-PE, Brazil. $\mathrm{C} 1+\mathrm{HS}=$ Treatment with HS in cycle $1, \mathrm{C} 1-\mathrm{HS}=$ Treatment without HS in cycle $1, \mathrm{C} 2+\mathrm{HS}=$ Treatment with HS in cycle 2, C2-HS = Treatment without HS in cycle 2.

Thus, considering the adequate nutrient contents in West Indian cherry leaves proposed by Bataglia and Santos (2001), it can be observed that plants were under conditions of luxury consumption of nutrients, except for $\mathrm{Fe}$, in both production cycles, so it is possible to state that these plants were on the threshold of nutrient excess or toxicity. Thus, lower chlorophyll indices in Cycle 1 are possibly associated with the higher $\mathrm{Zn}$ contents in the leaf tissue, as observed by Khurana and Chatterjee (2001). Nevertheless, Silva et al. (2010) observed symptoms of $\mathrm{Zn}$ toxicity in millet plants, with leaves showing a brownreddish color. The authors found that the $\mathrm{Zn}$ content in millet leaves necessary to cause toxicity was $451 \mathrm{mg} \mathrm{kg}^{-1}$.

The possible phytotoxic effect of excess $\mathrm{Zn}$ on West Indian cherry plants may have influenced the production and yield of the orchard (Figure 2D and 2E). Higher values of production and yield were observed in Cycle 2, regardless of $\mathrm{N}$ doses (Figure 2D and 2E). On the other hand, considering that West Indian cherry fruit production becomes stable from the fifth year (PETINARI; TARSITANO, 2002), it is natural that the first cycles have lower values of production and yield.

The yields obtained in this study were above average compared to those obtained by Calgaro and Braga (2012). In 2010, in the Senador Nilo Coelho irrigated perimeter, the authors observed average yields of $0.0 \mathrm{t}$ $\mathrm{ha}^{-1}$ in the first year, $12 \mathrm{tha}^{-1}$ in the second year, $15 \mathrm{t} \mathrm{ha}^{-1}$ in the third year, and $20 \mathrm{t} \mathrm{ha}^{-1}$ in the fourth and fifth years. Although the cultivation conditions are different, higher yields were observed in the present study, with $5.45 \mathrm{t} \mathrm{ha}^{-1}$ in the first cycle of West Indian cherry cultivated under HS application and $125 \%$ of the recommended $\mathrm{N}$ dose and $33.17 \mathrm{t} \mathrm{ha}^{-1}$ in the second cycle without HS application for the $\mathrm{N}$ dose of $75 \%$. 
HS have the potential to favor the development of plant roots, with the possibility of also increasing the shoots (CARON et al., 2015), and were initially believed to be able to contribute to increasing West Indian cherry yield. However, the doses of HS to be applied require adjustments based on field trials and according to the crop, demonstrating the need for further studies. In addition, HS application should be carefully performed, considering the pesticides and nutrients used, type of soil and crop, because HS contribute positively to the chemical and physical attributes of the soil, besides favoring the development of the root system and aerial part of plants (CARON et al., 2015).

Evaluating the morphological components and grain yield of maize cultivated with $\mathrm{N}$ associated with humic/fulvic acids in Paraná, Batista et al. (2018) observed that humic substances (fulvic acids and humic acids), alone or in association with $\mathrm{N}$, did not influence the morphological characteristics and yield components of the maize crop. These authors believe that the history of management used in the area, with high level of investment, may have contributed to the effect of HS and $\mathrm{N}$ on maize yield.
Regardless of HS application and production cycle of West Indian cherry, the leaf N content increased linearly as a function of the increment in $\mathrm{N}$ doses (Figure 2F). Ferreira (2014), studying nutrient accumulation in West Indian cherry seedlings fertilized with $\mathrm{N}$ and $\mathrm{K}$, concluded that the application of $\mathrm{N}$ doses linearly increased the accumulated amounts of $\mathrm{N}, \mathrm{Ca}, \mathrm{Mg}$ and $\mathrm{S}$ in the aerial part of the seedlings. Silva et al. (2016) observed an exponential increase in $\mathrm{N}$ content of leaf dry matter in yellow passion fruit as the $\mathrm{N}$ doses increased, in the presence of HS. HS in combination with urea reduce the action of the urease enzyme, thus resulting in a decrease in $\mathrm{N}$ losses and, in addition, contribute to a buffering effect on soil $\mathrm{pH}$, i.e. these substances maintain the soil more resistant to $\mathrm{pH}$ change (DONG et al., 2009; PERTUSATTI; PRADO, 2007).

HS application associated with $\mathrm{N}$ fertilization favored the reduction of leaf $\mathrm{Na}$ contents (Figure 3A). This trend was also observed for the leaf $\mathrm{K}$ contents in West Indian cherry plants in the second production cycle (Figure 3B). In this same cycle, the absence of HS application and the increasing doses of $\mathrm{N}$ enabled higher leaf $\mathrm{K}$ contents in the plants (Figure 3B). The observed contents suggest an excessive supply of nutrients, which may cease the increase in production (Law of diminishing returns), resulting in high nutrient contents in the plant (LEAL et al., 2007).
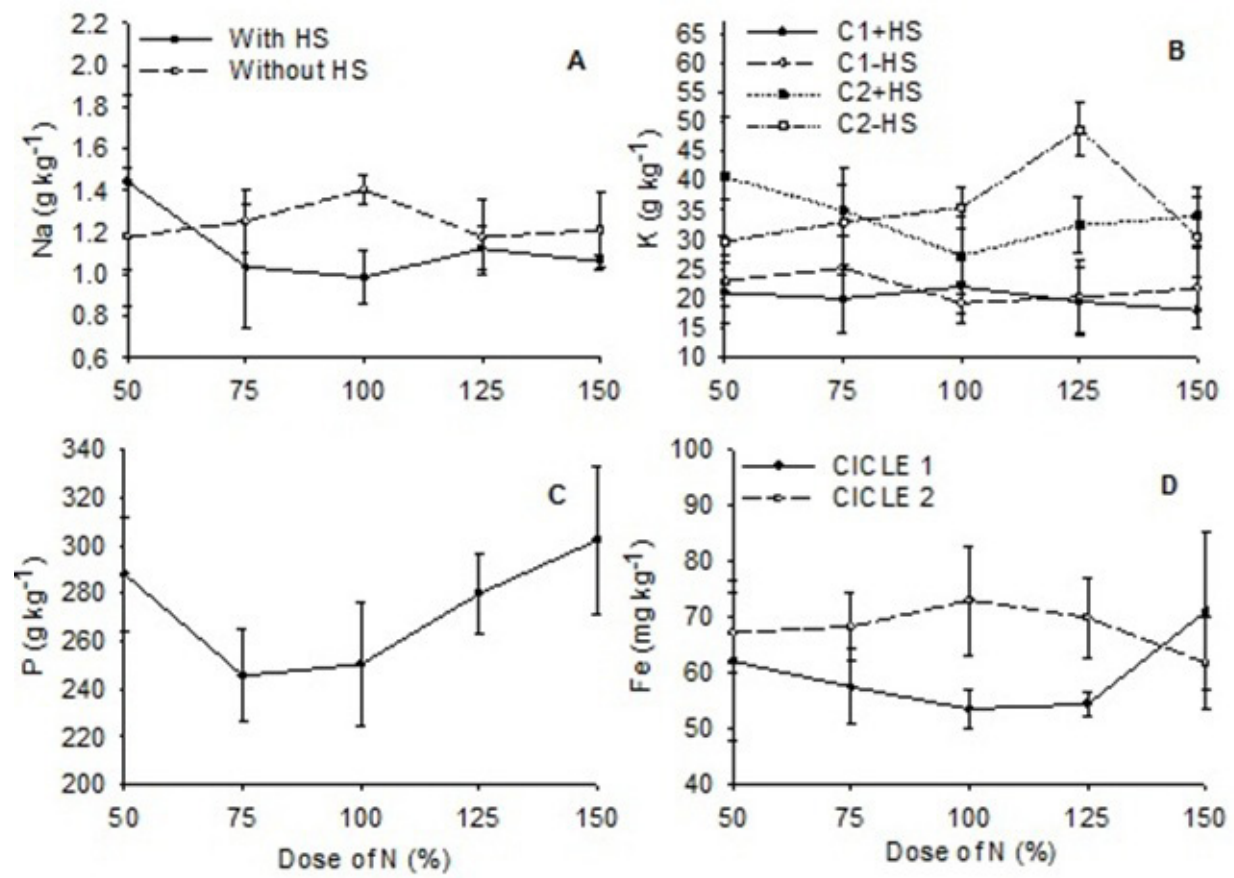

Figure 3. Leaf contents of sodium (A), potassium (B), phosphorus (C) and iron (D) in West Indian cherry fertigated with nitrogen $(\mathrm{N})$ and humic substances (HS) in Petrolina-PE, Brazil. $\mathrm{C} 1+\mathrm{HS}=$ Treatment with HS in cycle 1, C1-HS $=$ Treatment without $\mathrm{HS}$ in cycle $1, \mathrm{C} 2+\mathrm{HS}=$ Treatment with $\mathrm{HS}$ in cycle 2, C2-HS $=$ Treatment without HS in cycle 2. 
The application of $\mathrm{N}$ doses (75 to $150 \%$ ) also promoted increase in leaf $\mathrm{P}$ content (Figure 3C). Leaf Fe content decreased by $8.76 \%$ with the increase in $\mathrm{N}$ doses from 50 to $150 \%$ in Cycle 2. On the other hand, in Cycle 1, the opposite effect was observed for the Fe content in the leaves (Figure 3D).

The significant effects of the interaction between the production cycle of West Indian cherry and humic substances (CxHS) on the leaf contents of $\mathrm{Ca}$ and $\mathrm{Zn}$ are presented in Figure 4. In the treatment without HS, West Indian cherry plants had the highest leaf contents of $\mathrm{Ca}$ in Cycle 2 and $\mathrm{Zn}$ in Cycle 1.
No significant interactions were verified between the studied factors for the variables vitamin C (VIT C), $\mathrm{pH}$, soluble solids (SS), titratable acidity (TA) and SS/TA (Table 4). On the other hand, there was significant effect of production cycle on VIT C content $(\mathrm{p}<0.01)$ and $\mathrm{pH}$ of the fruits $(\mathrm{p}<0.01)$. Regardless of the application of HS and N doses, the VIT C content of West Indian cherry fruits from the first production cycle was $34.92 \%$ higher than that of fruits from the subsequent cycle (Table 4).

Table 4. Summary of analysis of variance for vitamin C (VIT C), pH, soluble solids (SS), titratable acidity (TA) and SS/TA ratio of fruits of West Indian cherry fertigated with nitrogen and humic substances.

\begin{tabular}{cccccc}
\hline Source of Variation & $\begin{array}{c}\text { VIT C } \\
\left(\mathrm{mg} 100 \mathrm{~mL}^{-1}\right)\end{array}$ & $\mathrm{pH}$ & $\begin{array}{c}\mathrm{SS} \\
\left({ }^{\mathrm{o}} \text { Brix }\right)\end{array}$ & $\begin{array}{c}\text { TA } \\
(\%)\end{array}$ & $\begin{array}{c}\text { Ratio } \\
(\mathrm{SS} / \mathrm{TA})\end{array}$ \\
Cicle I & $2820.09 \mathrm{a}$ & $3.19 \mathrm{~b}$ & $8.06 \mathrm{a}$ & $1.26 \mathrm{a}$ & $6.45 \mathrm{a}$ \\
Cicle II & $2090.29 \mathrm{~b}$ & $3.47 \mathrm{a}$ & $8.25 \mathrm{a}$ & $1.27 \mathrm{a}$ & $6.50 \mathrm{a}$ \\
CV $(\%)$ & 10.61 & 2.73 & 10.25 & 6.01 & 12.34 \\
With SH & $2483.02 \mathrm{a}$ & $3.34 \mathrm{a}$ & $8.30 \mathrm{a}$ & $1.28 \mathrm{a}$ & $6.50 \mathrm{a}$ \\
Without SH & $2427.35 \mathrm{a}$ & $3.32 \mathrm{a}$ & $8.02 \mathrm{a}$ & $1.25 \mathrm{a}$ & $6.50 \mathrm{a}$ \\
CV (\%) & 6.84 & 2.58 & 7.75 & 7.64 & 11,39 \\
\hline & & Value $\mathbf{F}$ & & & \\
Cicle (C) & $156.87^{* *}$ & $187.85^{* *}$ & $1.01^{\text {ns }}$ & $1.20^{\text {ns }}$ & $0.01^{\text {ns }}$ \\
Humic Sub. $(H S)$ & $2.20^{\text {ns }}$ & $1.56^{\text {ns }}$ & $3.87^{\text {ns }}$ & $2.91^{\text {ns }}$ & $0.001^{\text {ns }}$ \\
Dose of N & $1.39^{\text {ns }}$ & $1.06^{\text {ns }}$ & $0.95^{\text {ns }}$ & $1.07^{\text {ns }}$ & $0.56^{\text {ns }}$ \\
CV $(\%)$ & 11.16 & 3.19 & 8.82 & 11.76 & 12.20 \\
\hline CxHS & $5.16^{\text {ns }}$ & $0.36^{\text {ns }}$ & $0.002^{\text {ns }}$ & $0.86^{\text {ns }}$ & $0.28^{\text {ns }}$ \\
CxN & $0.88^{\text {ns }}$ & $0.21^{\text {ns }}$ & $1.37^{\text {ns }}$ & $0.82^{\text {ns }}$ & $0.97^{\text {ns }}$ \\
HSxN & $1.98^{\text {ns }}$ & $1.23^{\text {ns }}$ & $2.14^{\text {ns }}$ & $1.06^{\text {ns }}$ & $1.32^{\text {ns }}$ \\
CxHSxN & $1.78^{\text {ns }}$ & $0.59^{\text {ns }}$ & $0.97^{\text {ns }}$ & $1.32^{\text {ns }}$ & $1.49^{\text {ns }}$ \\
\hline
\end{tabular}

$\mathrm{ns}=$ not significant; $* *$ significant at $1 \%$ probability level; $*$ significant at $5 \%$ probability level. Means followed by the same letter in the column do not differ statistically by $\mathrm{F}$ test with $\mathrm{P} \leq 0.05$.

The $\mathrm{pH}$ of West Indian cherry fruits increased by $8.77 \%$ from the first to the second production cycle. The values found in the present study are close to those cited by Lima et al. (2014) and similar to those obtained by Maciel et al. (2010) and Santos et al. (2012). In West Indian cherry fruits, including in ripe ones, $\mathrm{pH}$ is a parameter with low variability (LIMA et al., 2014). In view of the physicochemical characteristics analyzed, this variable had the lowest coefficient of variation.

Pulp $\mathrm{pH}$ is a characteristic of fruits related to the post-harvest shelf life (DURIGAN et al., 2004); the most suitable fruits for fresh consumption are the least acidic, while the most acidic ones are more used by food industries (CAMPOS et al., 2007). Silva et al. (2015), when evaluating the quality of yellow passion fruit under the application of HS and $\mathrm{N}$ doses, concluded that $\mathrm{N}$ fertilization combined with HS increases fruit $\mathrm{pH}$ and titratable acidity.
For the parameters SS, pH, TA and VIT C, the data of the present study meet the characteristics and minimum composition ( $\mathrm{SS}-5.5^{\circ} \mathrm{Brix}$; $\mathrm{pH}-2.8$; TA - $0.8 \%$ and VIT $\mathrm{C}-800 \mathrm{mg} / 100 \mathrm{~g}$ ) established by the Ordinance $\mathrm{N}^{\circ} 58$ of August 30, 2016 of the Ministry of Livestock, Agriculture and Food Supply - MAPA, which approves the General Technical Regulation for setting the standards of identity and quality for fruit pulps. 

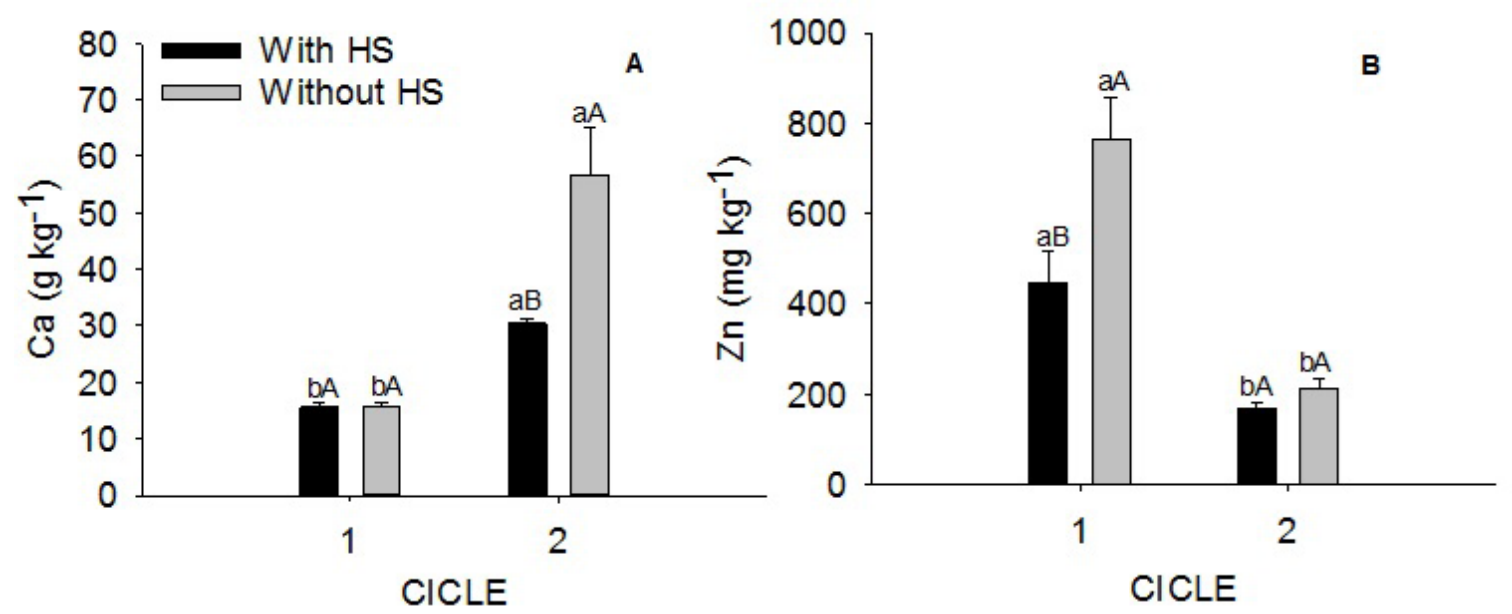

Figure 4. Leaf contents of calcium (A) and zinc (B) in West Indian cherry plants as a function of production cycle and fertigation with humic substances in Petrolina-PE, Brazil. Columns followed by the same lowercase letter between cycles and uppercase letter between humic substances do not differ statistically by test $\mathrm{F}$ with $\mathrm{P} \leq 0.05$.

\section{Conclusions}

Except for leaf nitrogen content, which increased linearly with the applied doses, the leaf contents of nutrients in West Indian cherry showed a stochastic pattern in relation to the increase in $\mathrm{N}$ availability and application of humic substances.

Fertigation with HS, at the applied dose, reduced the production and yield of West Indian cherry, whereas increasing $\mathrm{N}$ doses did not increase its production and yield.

Application of humic substances and $\mathrm{N}$ doses did not alter the post-harvest quality of West Indian cherry fruits.

\section{References}

AOAC - Association Of Oficial Analytical Chemistral. Official methods of analysis of the Association of Official Analytical Chemistry. $16^{\text {th }}$ ed. Washington: AOAC, 1997. p.1115.

BARBOZA, S.B.S.C.; TAVARES, E.D.; MELO, M.B. Instruções para o cultivo da acerola. Aracaju: EmbrapaCPATC, 1996. 42p.

BATAGLIA, O. C.; SANTOS, W. R. Estado nutricional de plantas perenes: avaliação e monitoramento. Informações agronômicas IPNI, Piracicaba, n.96, p.3-8, 2001.
BATISTA, V.V.; ADAMI, P.F.; Ferreira, M.L.; GIACOMEL, C.L.; SILVA, J.S.; OLIGINI, K.F. Ácidos húmicos/fúlvicos e nitrogênio na produtividade da cultura do milho. Brazilian Journal of Biosystems Engineering, Tupã, v. 12, n.3, p.257-267, 2018.

CALGARO, M.; BRAGA, M.B. A cultura da acerola. 3.ed. Brasília: Embrapa, 2012. 144p.

CAMPOS, V.B.; CAVALCANTE, L.F.; DANTAS, T.A.G.; MOTA, J.K.M.; RODRIGUES, A.C.; DINIZ, A.A. Caracterização física e química de frutos de maracujazeiro amarelo sob adubação potássica, biofertilizante e cobertura morta. Revista Brasileira de Produtos Agroindustriais, Campina Grande, v.9, n.1, p.59-71. 2007.

CARON, V.C.; GRAÇAS, J.P.; CASTRO, P.R.C. Condicionadores do solo: ácidos húmicos e fúlvicos. Piracicaba: ESALQ/USP, 2015.

CAVALCANTI, F.J. de A. Recomendações de adubação para o Estado de Pernambuco: 2a. aproximacao. 3.ed. Recife: Instituto Agronômico de Pernambuco, 2008. 212 p.

CUNHA, M.D.S.; CAVALCANTE, I.H.L.; MANCIN, A.C.; ALBANO, F.G.E MARQUES, A.S. Impact of humic substances and nitrogen fertilising on the fruit quality and yield of custard apple. Acta Scientiarum. Agronomy, Maringá, v.37, n.2, p.211-218, 2015. 
DONG, L.; KREYLOS, A.L.; YANG, J.; YUANA, H.; SCOWB, K.M. Humic acids buffer the efects of urea on soil ammonia oxidizers and potencial nitrification. Soil Biology Biochemistry, Oxford, v.4, n.8, p.1612-1621, 2009.

DURIGAN, J.F.; SIGRIST, J.M.M.; ALVES, R.E.; FILGUEIRAS, H.A.C.; VIEIRA, G. Qualidade e tecnologia pós-colheita do maracujá. In: LIMA, A. A.; CUNHA, M.A. P. Produção e qualidade na passicultura. Cruz das Almas: Embrapa Mandioca e Fruticultura, 2004. p.281-304.

ERNANI, P.R.; ROGERI, D.A.; PROENÇA, M.M.; DIAS, J. Addition of nitrogen had no effect on yield an quality of apples in an high density orchard carrying a dwarf rootstock. Revista Brasileira de Fruticultura, Jaboticabal, v.30, n.4, p.1113-1118, 2008.

FERRARA, G.; BRUNETTI, G. Influence of foliar applications of humic acids on yield and fruit quality of table grape cv. Itália. Journal International des Sciences de la Vigne et du Vin, Bordeaux, v.42, n.2, p.79-87, 2008 .

FERREIRA, K.S. Crescimento e acúmulo de nutrientes em mudas de aceroleira adubadas com nitrogênio e potássio. 2014. Dissertação (Mestrado em Ciências Agrárias) - Universidade Federal de São João Del Rei, Sete Lagoas, 2014.

FRANZÃO, A.A.; MELO, B. A cultura da aceroleira. Uberlandia: Núcleo de estudo em fruticultura no Cerrado, Universidade Federal de Uberlandia, Instituto de Ciencias Agrárias, 2003. p.12. Disponível em: http://www. fruticultura.iciag.ufu.br/aceroleira.htm. Acesso em: 30 jun. 2017.

HAWKESFORD, M.; HORST, W.; KICHEY, T.; LAMBERS, H.; SCHJOERRING, J.; MOLLER, S.I.; WHITE, P. Functions of macronutrients. In: MARSCHNER, P. (ed.). Marschner's mineral nutrition of higher plants. New York: Elsevier, 2012. p.135-189.

INSTITUTO ADOLFO LUTZ. Normas analíticas: métodos físicos e químicos para análise de alimentos. 4.ed. São Paulo, 2008. 1002p.

IBGE - Instituto Brasileiro de Geografia e Estatística. Acerola do Brasil por quantidade produzida. Censo agropecuário. Rio de Janeiro, 2017. Disponível em: https:/censoagro2017.ibge.gov.br/ templates/censo_agro/resultadosagro/agricultura. html ?localidade $=0 \&$ tema $=76215>$. Acesso: 06 jun. 2019.
KHURANA, N.; CHATTERJEE, C. Influence of variable zinc on yield, oil content, and physiology of sunflower. Communications in Soil Science and Plant Analysis, New York, v.32, n.19-20, p.3023-3030, 2001.

LEAL, R.M.; NATALE, W.; PRADO, R.M.; ZACCARO, R.P. Adubação nitrogenada na implantação e na formação de pomares de caramboleira. Pesquisa Agropecurária Brasileira, Brasília, v.42, n.8, p.1111-1119, 2007.

LIMA, P.C.C.; SOUZA, B.S.; SOUZA, P.S.; BORGES, S.S.; ASSIS, M.D.O. Caracterização e avaliação de frutos de aceroleira. Revista Brasileira de Frutiultura, Jaboticabal, v.36, n.3, p.550-555, 2014.

LIMA, R.L.S.; SIQUEIRA, D.L.; WEBER, O.B.; CECON, P.R. Teores de macronutrientes em mudas de aceroleira (Malpighia emarginata D.C.) em função da composição do substrato. Ciência e Agrotecnologia, Lavras, v.30, n.6, p.1110-1115, 2006.

LOBO, D.M.; SILVA, P.C.C.; COUTO, J.L.; SILVA, M.A.M.; SANTOS, A.R. Características de deficiência nutricional do amendoinzeiro submetido à omissão de $\mathrm{N}$, P, K. Bioscience Journal, Uberlândia, v.28, n.1, p.69-76, 2012.

MACIEL, M.I.S.; MÉLO, E.; LIMA, V.; SOUZA, K.A.; SILVA, W. Caracterização físico-química de frutos de genótipos de aceroleira (Malpighia emarginata D.C.). Ciência e Tecnologia de Alimentos, Campinas, v.30, n.4, p.865-869, 2010.

MIRANDA, J.M.D.S.; CAVALCANTE, I.H.L.; OLIVEIRA, I.V.M.; LOPES, P.R.C.; ASSIS, J.S. Fruit quality of Eva e Princesa apples grown under nitrogen fertigation in semiarid climate. Revista Brasileira de Engenharia Agrícola e Ambiental, Campina Grande, v.19, n.10, p.967-972, 2015.

NOWAKI, R.H.D.; FILHO, A.B.C.; FARIA, R.T.; WAMSER, A.F.; CORTEZ, J.W.M. Effect of nitrogen fertilization on yield and quality of watermelon, cv. top gun. Revista Caatinga, Mossoró, v.30, n.1, p.164-171, 2017.

PERTUSATTI, J.; PRADO, A.G.S. Buffer capacit of humic acid: thermodynamic appoach. Jornal of Colloid and Interface Science,v.314, n. 2, New York, p.484-489. 2007.

PETINARI, R. A.; TARSitAnO, M. A. A. Análise econômica da produção de acerola para mesa, em Jales-SP: um estudo de caso. Revista Brasileira de Fruticultura, Jaboticabal, v.24, n.2, p.411-415, 2002. 
PRASAD, R.; HOCHMUTH, G.J.; BOOTE, K.J. Estimation of nitrogen pools in irrigated potato production on sandy soil using the model Substor. Plos One, California, v.10, n.1, p.e0117891, 2015.

SANTOS, S.M.L.; VASCONCELOS, A.M.; OLIVEIRA, V.S.; CLEMENTE, E.; COSTA, J.M.C. Evaluation of physical and physicochemical characteristics of Malpighia emarginata D.C. from the state of Ceará. International Journal of Biochemistry, Bristol, v.2, n.4, p.152-163, 2012.

SILVA, F.A.S.; AZEVEDO, C.A.V. Principal Components Analysis in the Software Assistat-Statistical Attendance. In: WORLD CONGRESS ON COMPUTERS IN AGRICUlture, 7., 2009, Orlando. Proceedings [...]. Reno: American Society of Agricultural and Biological Engineers, 2009. p.22-24.

SILVA, F.C. Manual de análises químicas de solos, plantas e fertilizantes. 2.ed. rev. ampl. Brasília, DF: Embrapa Informação Tecnológica, 2009. p.370.
SILVA, K.A,; RODRIGUES, M.S.; CUNHA,J.C.; ALVES, D.C.; FREITAS, H.R.; LIMA, A.M.N. Levantamento de solos utilizando geoestatística em uma área de experimentação agrícola em Petrolina-PE. Comunicata Scientiae, Bom Jesus, v.8, n.1,p.175-180, 2017.

SILVA, R.L.; CAVALCANTE, I.H.L.; LIMA, A.M.N.; BARBOSA, L.F S; SOUZA, C.; SOUSA, E.S.; LESSA, T.B.S.; CAVALCANTE, L.F. Effect of humic substances and nitrogen fertilization on yellow passion fruit cultivation in the Brazilian semiarid region. African Journal of Agricultural Research, Abuja, v.11, n.35, p.3307-3313, 2016.

SILVA, R.L; CAVALCANTE, I.H.L.; SOUSA, K.S.M.; GALHARDO, C.G.; SANTANA, E.A.; LIMA, D.D. Qualidade do maracujá amarelo fertirrigado com nitrogênio e substâncias húmicas. Comunicata Scientiae, Bom Jesus, v.6, n.4, p.479-487, 2015.

SILVA, T.M.R.; PRADO, R.M.; VALE, D.W.;AVALHÃES, C.C.; PUGA, A.P.; FONSECA, I.M. Toxicidade do zinco em milheto cultivado em Latossolo Vermelho Distrófico. Revista Brasileira de Ciências Agrárias, Recife, v.5, n.3, p.336-340, 2010. 